\title{
INTERNATIONAL MIGRATION AND DEVELOPMENT: PERSPECTIVE FROM ORIGIN COUNTRIES OF MIGRANTS*
}

\author{
Laxman Singh Kunwar
}

\begin{abstract}
This paper seeks to critically analyze the role of migration to carry out development in origin countries of migrants. Now, migration and development; development in the origin of migrants' is being widely discussed among governmental and non-governmental institutions in the world. At the same time the flow of migrants' from economically less developed nations or regions to more developed nations or regions have been increased significantly. The volume of remittances also has been increased every year. Some countries adopted the policy of labour export since a long period of time but there is no achievement in development in the countries. The aim of this paper is to relate achievement in development of migrants' origin countries with remittances with the help of available literature. The existing debate on migration and development is also a part of review of this paper. The migration-development relationship is complex and multidimensional, and that there is variation from one context to another with differences in the nature of migration and in the economic, political and social situations in origin and destination. It would be problematic and insufficient to analyze migration process and its consequences with the help of any single theory or approach of migration, because migration process has far reaching effects on national and international level and varies differently for different part of world on the basis of achievement on social, political, and economic development.
\end{abstract}

Keywords: international migration, development, origin countries of migrants

\section{GENERAL BACKGROUND}

Migration of population is a demographic process which is a complex phenomenon and varies in nature. It is closed bound up with many other socio-economic variables, and are the result of the development of productive forces and the system of production relations. Migration promotes exchange in work skills and experiences, enhances the development of the individual, and influences the size and shape of families and age

\footnotetext{
This paper was submitted to REMESO Graduate School on Migration, Ethnicity and Society, Department of Social and Welfare Studies, Linkoping University, Sweden. The author is grateful to course directors Peo Hansen and Branka Likic-Brboric for their valuable comments with suggestions.

** Kunwar is Lecturer in Population Studies and working as a Head of Department of Population Studies, Patan Multiple Campus, Tribhuvan University
} 
and age structure of population. Migration has always had both positive and negative impacts on migrants themselves, their origin and their destinations.

Now a days, there is much more concern and debate on the issues of migration and development. The last two decades has seen an increase in the scale and complexity of international migration (Hugo, 2007). The linkage of development cooperation and migration policies has been promoted massively by international organizations from 2000 onwards. Than after Asian Development Bank (2004) as well as national development assistance agencies such as DFID and USAID started to examine international migration's contribution to development in origin countries of migrants (Hugo, 2007). The UN Secretary General produced a comprehensive report on International Migration and Development (United Nations, 2006). This opened the door of interaction among the representative of all states at the UN General Assembly on 14-15 September 2006. In the early of $21^{\text {st }}$ century, analyzing the flow of SouthNorth migration considered as problem for national identity, social cohesion and threat to national security. Now, politicians and government's official are emphasizing international migration, as a means to bring economic and social development in the countries of origin (Castles, 2008).

'The demand for workers in capital-rich but labour short countries in the Gulf region in 1970s started large scale labour migration from and within Asia and that continues to this day' (Asis, 2005). Mexican migration to the United States has been a major area of contention for U.S.-Mexico bilateral relations since the 1900s. Historically, there have been periods of shared interests in promoting migratory flows (Esmeralda RodriguezScott, 2002). The government of countries like Philippines, India, Sri Lanka, Turkey and Morocco took the policy of labour export to the economically developed regions of world. The outcomes of those labour export policies were often disappointing (IOM, 2008).

Now, remittances have become focal point within the migration-development nexus. Remittances have been taken as a part of solution for development and poverty reduction strategy in sending or origin countries of migrants. Here, question arises why above mentioned labour exporting countries are not being able to achieve economic development, even though; those countries have a long history and experience of emigration and receiving remittances.

\section{OBJECTIVES OF THE STUDY}

The main objectives of this study are as follows:

- To identify the theoretical debates on outcomes migration mainly in origin countries of international migrants', 
- To analyze some demographic and economic scenario of origin and destination of international migrants',

- To analyze the role of migration in development of countries of origin of international migrants' by remittances.

\section{DATA AND METHOD}

This study was carried out with the help of available relevant literature related with objectives of the study. Therefore the study is based on various secondary sources of data and information.

\section{DEBATES ON MIGRATION AND DEVELOPMENT}

Development economists (neo-classical approach) focused the labour migration as an integral part of modernization, which was emphasized much more during the period of 1950s-1960s. The effect of development on migration and migration on development considered as vice versa. Labour surplus at origin and their inflow of remittances was expected to improve productivity and incomes in countries of origin. Countries like Philippines, Turkey and Morocco adopted this view, expecting labour export would facilitate their economic development (Castles 2008; Massey, et al, 1998).

During the period from 1950s-1980s the debate between neo-classical economic theory and historical institution theory (Neo- Marxist approach) were viewed migration process contradictory. Development economists' analyzed migration on the basis of neo-classical approach in which, individual decision to migrate based on rational economic consideration of relative benefits and costs, and migrants are quite aware of their wages and employment opportunities at destination, and migration is mainly influenced by economic motive. The more existence of economic disparities between origin and destination creates migration flows. In the long run migratory flows should help to lead economic equilibrium by equalizing wages and conditions in developed and underdeveloped regions of world. In the beginning of development, in poor countries stimulates migration which enhanced development and tends to income equilibrium eliminating the root causes of migration, as a result less migration. Todaro (1969), and Harris and Todaro (1970) elaborated the basic two-sector model of rural to-urban labour migration. "Harris-Todaro model" has remained the basis of neoclassical migration theory since then (de Hass, 2008).

Contrasting with the view of neo-classical, the historical- institutional approach explained migration mainly as a way of mobilizing cheap labour for capital. According to this approach underdevelopment was a legacy of European colonialism, exploiting the resources of poor countries to make the rich country richer. This analysis lay in Marxist political economy-dependency theory. The penetration of multi-national 
corporations into less developed economics accelerated rural change, leading to poverty, displacement of workers, rapid urbanization and the growth of informal economics. Core-periphery and semi-periphery division, and dependency stimulate migration which increased dependency of poor countries resulting impoverishment and worse income; as a result third world labour freely available for capital in core economics. Emmanuel Waller stein's $(1974 ; 1980)$ world-systems theory classified countries according to their degree of dependency, and distinguished between the capitalist "core" nations, followed by the "semi-peripheral", "peripheral", and isolated nations in the "external" area, which were not (yet) included in the capitalist system (de Hass, 2008). Core and periphery are economically developed and developing regions respectively, and semi-periphery which is located between core and periphery, they benefit from the periphery through unequal exchange relations. At the same time, the core benefits from the semi-periphery through unequal exchange relations (Wallerstein, 1980).

De Hass (2008) analyzed the main debate between 'development' economics approach (neo-classical views) as 'migration optimists' and historical- institutional approach (neo-Marxist views) as 'migration pessimists". The summary of views on migration and development is given in Table 1.

Table: 1 Opposing views on Migration and development

\begin{tabular}{ll}
\hline Migration Optimists & Migration Pessimists \\
\hline Functionalist & Structuralist \\
Neo-classical & Neo-Marxist \\
Modernization & Disintegration \\
Net North-South Transfer & Net South-North Transfer \\
Brain gain & Brain Drain \\
More equality & More inequality \\
Remittance investment & Remittance Consumption \\
Development & Dependency \\
Less Migration & More migration \\
\hline
\end{tabular}

Source: de Hass, 2008

Theoretical models began to emerge from 1970s to bridge the old divisions and to work towards a more comprehensive understanding of migratory process. Among them Zelinsky (1971), forwarded his views on 'Mobility Transition', by developing five phase of mobility transition parallel with vital transition as "essential components modernization process.According to him at the beginning process of modernization and industrialization, there is frequently an increase in emigration, mainly due to population growth and decline in rural employment and low wage levels. As 
industrialization proceeds, labour supply declines and domestic wags levels rise; as a result emigration falls and labour immigration begins to take its place (Zelinsky, 1971).

The other new approaches of migration are new economics of labour migration (NELM), based on neo classical paradigm in which income maximization tends towards economic equilibrium in areas of origin and destination. It was particularly Stark $(1978 ; 1991)$ who revitalized thinking on migration in and from the developing world by placing the behavior of individual migrants in a wider societal context and by considering not the individual, but the family or the household as the most appropriate decision-making unit (de Hass, 2008).

The other new theories are Segmented market theory developed on the basis of labour demand of employees; Network theory developed on the basis of role of collective agency in migratory process; Transnational theory developed on the basis of link (social, political, economic, cultural and other) across the border due to development of communication and transportation technologies; Migration system theory based on migration alters the social, cultural, economic, and institutional conditions at both the sending and receiving areas (Mabogunje, 1970); Livelihood strategy based on argued that the poor cannot only be seen as passive victims of global capitalist forces but try to actively improve their livelihoods within the constraining conditions they live in. A livelihood comprises the capabilities, assets (including both material and social resources), and activities required for a means of living (Carney, 1998).

In conclusion, the most of the debates on migration and development have been concentrated around the opposing views between neo-classical and neo-Marxist approaches. The migration process and their outcomes with complexities reflect that no any single migration theory is found enough to explain migration and development process. There is a gap between experienced gain by origin and destination countries and migration theories especially in describing development of migrants' origin. The increasing complexities in fields of demographic, political, and socio-economic areas of world and achieving progress in information and transportation, it would be further difficult to explain migration and development theory or approach being satisfied for sending and receiving countries.

\section{DEMOGRAPHIC AND ECONOMIC SCENARIO OF COUNTRIES OF ORIGIN AND DESTINATION}

Population movements in response to demographic growth and development of production and trade have always been part of human history. There has been an 
increasing volume of global migration from Developing to Developed economics. Table (2) shows the number of international migrants in More Developed Countries (MDCs) and Less Developed Countries (LDCs) between 1960 and 2005.

Table 2: International Migration between Less Developed and More Developed Countries

\begin{tabular}{|c|c|c|c|c|c|c|c|c|}
\hline Major area & \multicolumn{2}{|c|}{$\begin{array}{c}\text { Estimated number } \\
\text { of international } \\
\text { migrants at mid- } \\
\text { year (millions) }\end{array}$} & \multicolumn{2}{|c|}{$\begin{array}{c}\text { Average annual } \\
\text { growth of the } \\
\text { international } \\
\text { migrants }\end{array}$} & \multicolumn{2}{|c|}{$\begin{array}{c}\text { International } \\
\text { migrants as a } \\
\text { share of the } \\
\text { population } \\
\text { (percent) }\end{array}$} & \multicolumn{2}{|c|}{$\begin{array}{c}\text { Distribution of } \\
\text { international } \\
\text { migrants by } \\
\text { region }\end{array}$} \\
\hline World & 1960 & 2005 & $1960 / 70$ & $2000-2005$ & 1960 & 2005 & 1960 & 2005 \\
\hline $\begin{array}{c}\text { More Developed } \\
\text { Countries }\end{array}$ & 32.3 & 120.6 & 1.7 & 1.7 & 3.4 & 9.4 & 42.8 & 63.3 \\
\hline $\begin{array}{c}\text { Less Developed } \\
\text { Countries }\end{array}$ & 43.1 & 70.0 & 0.0 & 1.2 & 2.1 & 1.4 & 57.2 & 36.7 \\
\hline
\end{tabular}

Source: United Nations Population Division, Trends in the Migrant Stock, the 2005 Revision

During this period in MDCs migrants were increased from 3.4 to 9.4 percent while for LDCs it fell from 2.1 to 1.4 percent as residents. Now all more developed nations experience significant proportions immigration. The more developed regions in world is gaining and less developing regions is losing the percentage sharing of intentional migrants over the time.

Table (3) compares the actual and projected growth in the numbers in the workforce entry age groups (15-24) in Europe and Asia. In Europe they began to decline in the 1980s and will fall from 100,904 in 2000 to 65,880 in 2040. In Asia the numbers will continue to grow to 670,000 in 2020 but will decline thereafter. The existing and projected scenario of youth population (15-25 years) between two continents reflects the labour force situation of MDCs and LDCs of world. The situation of demographic deficit in MDCs and demographic boom in LDCs are favorable environment for pull and push factors of migration. Between 2010s and 2030s, at current immigration flows, the decline in EU-25's working age population will entail a fall in the number of employed people of some 20 million. Such development will have a huge impact on overall economic growth, the functioning of internal market and the competitiveness of EU enterprise. In this context ..., more sustained immigration flows could increasingly be required to meet the needs of EU labour market and ensure Europe's prosperity (CEC, 2005). 'Africa could provide Europe with raw materials for its industry, nutrition for its population, land for it's over population, labour for its unemployment, and market for its products' (Coudenhoven-Kalergi , 1929). 
Table 3: Europe and Asia Population Aged 15-24, 1960-2000 and Projected 2020 and 2040

\begin{tabular}{llll}
\hline \multicolumn{1}{l}{ Europe } & & & \\
\hline \multicolumn{3}{l}{ Population Aged 15-24 } & \multicolumn{2}{l}{ Annual Percentage Growth Per Annum } \\
\hline Year & Number ('000) & Percent & \\
1960 & 91,743 & 15.18 & \\
1980 & 112,453 & 16.24 & 2.76 \\
1985 & 109,214 & 15.47 & -0.39 \\
1990 & 104,124 & 14.43 & -0.44 \\
2000 & 100,904 & 13.86 & -0.18 \\
2020 & 73,492 & 10.42 & -0.63 \\
2040 & 65,840 & 9.97 & -1.30 \\
\hline Asia & & & \\
\hline Population Aged 15-24 & Annual Percentage Growth Per Annum \\
\hline Year & Number ('000) & Percent & \\
1960 & 283,539 & 17.34 & \\
1980 & 489,013 & 19.43 & 2.76 \\
1985 & 565,195 & 20.52 & 2.94 \\
1990 & 610,458 & 20.25 & 1.55 \\
2000 & 615,201 & 17.64 & 0.08 \\
2020 & 669,315 & 15.60 & 0.42 \\
2040 & 653,518 & 13.79 & -0.12 \\
\hline
\end{tabular}

Source: United Nations, 2003

Remarkable income differentials on per capita income can be observed between origin and destination countries as Table (4) indicates. This is helpful to understand the economic situations of MDCs and LDCs of the world. It is well established argument, that an income gap or wage differential between the regions stimulates the migration process and wage rate is determined with available labour force. 
Table 4: Asia: Gross National Income per Capita (\$US), 2003

\begin{tabular}{lclc}
\hline Origin Countries & \multicolumn{3}{l}{ Destination Countries } \\
\hline Bangladesh & 400 & UK & 28,350 \\
Bhutan & 660 & France & 24,770 \\
Cambodia & 310 & Australia & 21,650 \\
China & 1,100 & US & 37,610 \\
India & 530 & Canada & 23,930 \\
Indonesia & 810 & Germany & 25,250 \\
Laos & 320 & Italy & 21,560 \\
Nepal & 240 & Spain & 16,990 \\
Pakistan & 470 & Sweden & 28,840 \\
Philippines & 1,080 & Saudi Arabia & 8,530 \\
Sri Lanka & 930 & Singapore & 21,230 \\
Vietnam & 480 & Japan & 34,510 \\
Myanmar & Estimated to be $\$ 765$ or less & United Arab Emirates & to be $\$ 9,386$ \\
& & & or more \\
\hline
\end{tabular}

Source: World Bank, 2004

Similarly, differences in the political environment and level of freedom between nation states will continue to be a force for international migration. More specifically, 3Ds (Demography, Development and Democracy), development in transportation system, information and communication technology, role of recruitment industries (agents, recruiters, traffickers), and internationalization of labour market would further increases the flow of international migrants to MDCs of world.

\section{REMITTANCES: FOR HOUSEHOLD CONSUMPTION OR DEVELOPMENT?}

Remittances have been one of the fore front agenda in international migration. Some countries have a long experience of receiving remittances and its' implication. This section will discuss about migrants main areas of working at destination and investment of remittances in their origin.

Remittances have become an important source of development financing, and discussed measures to increase remittances and there by their positive impact on development (Ratha, 2003). Small amount of remittances can substantially improve the livelihoods and well being of migrants and their families in sending countries. A range of empirical studies have conformed the positive contribution of international remittances to household welfare, nutrition, food, health and leaving conditions in 
migrants sending places and regions(de Hass, 2008). Remittances have become a new 'development mantra': government and officials believe that money send home by migrants can be a recipe for local, regional and national level development (Kapur, 2004).

As most remittances, either in cash or kind, are sent back to the migrants' family members and relatives, the most obvious impact of remittances is to support the subsistence and incomes of households in the place of origin. Remittances have generally better local investment potential where modern and flexible financial infrastructures exist and where government policies are capable of supporting migrants' needs (Dang Nguyen Anh, 2005).

The Table (5) shows world's six countries who, are sharing at least near about 50 per cent remittances of total remittances during the period 1995-2001.

Table 5: Remittances to selected countries, 1995-2001

\begin{tabular}{lccccccc}
\hline & 1995 & 1996 & 1997 & 1998 & 1999 & 2000 & 2001 \\
\hline Developing Countries (\$bil) & 48 & 53 & 63 & 60 & 65 & 65 & 72 \\
India & 6.2 & 8.8 & 10.3 & 9.5 & 11.1 & 9.2 & 10 \\
Mexico & 4.4 & 5 & 5.5 & 6.5 & 6.6 & 7.6 & 9.9 \\
Philippines & 5.4 & 4.9 & 6.8 & 5.1 & 6.9 & 6.2 & 6.4 \\
Morocco & 2 & 2.2 & 1.9 & 2 & 1.9 & 2.2 & 3.3 \\
Egypt & 3.2 & 3.1 & 3.7 & 3.4 & 3.2 & 2.9 & 2.9 \\
Turkey & 3.3 & 3.5 & 4.2 & 5.4 & 4.5 & 4.6 & 2.8 \\
Sub-total & 24.5 & 27.5 & 32.4 & 31.9 & 34.2 & 32.7 & 35.3 \\
\hline Share of sub-total & $13 \%$ & $17 \%$ & $16 \%$ & $16 \%$ & $17 \%$ & $14 \%$ & $14 \%$ \\
India & $9 \%$ & $10 \%$ & $9 \%$ & $11 \%$ & $10 \%$ & $12 \%$ & $14 \%$ \\
Mexico & $11 \%$ & $9 \%$ & $11 \%$ & $9 \%$ & $11 \%$ & $10 \%$ & $9 \%$ \\
Philippines & $4 \%$ & $4 \%$ & $3 \%$ & $3 \% 3 \%$ & $3 \%$ & $3 \%$ & $5 \%$ \\
Morocco & $7 \%$ & $6 \%$ & $6 \%$ & $6 \%$ & $5 \%$ & $4 \%$ & $4 \%$ \\
Egypt & $7 \%$ & $7 \%$ & $7 \%$ & $9 \%$ & $7 \%$ & $7 \%$ & $4 \%$ \\
Turkey & $51 \%$ & $52 \%$ & $52 \%$ & $54 \%$ & $53 \%$ & $51 \%$ & $49 \%$ \\
Big 6 share & & & & & & \\
\hline
\end{tabular}

Source: www.worldbank.org/prospects/gdf2003/gdf_statApp_web.pdf (p.198)

The table shows the flow of remittances for short period of time even though these countries are involving for labour sending and drawing remittances since early 1960s. Therefore, the role of remittances can be questioned in achieving development in origin of migrants. 
The extent to which households succeed in achieving these goals of livelihood improvement critically depends on the destination and selectivity of migrants' destination. Migration and remittances are often ascribed a poverty reducing role. However, the fact that migration tends to be a selective process means that most remittances do not tend to flow to the poorest members of communities (CDR, 2002) nor to the poorest countries (Kapur 2003; Kapur \& McHale, 2003).

The effect of migration on income distribution and social inequality is primarily a function of migration selectivity. Migrants mainly originate from relatively wealthy household, which is often the case migration more likely to imply greater inequality in the community of origin (Black, Natali and Skinner, 2005). Increasing income inequality can exacerbate relative deprivation, and further increase aspirations to migrate among non-migrants. In unfavorable investment environment remittances might significantly improve livelihoods of migrants-sending families and communities, but do little promote while provoking passive dependence on remittances and even decreases economic growth. The major impact of remittances in the origin areas is the changes in the pattern of household expenditure, improved living conditions, social security, and improved education and health.

The ties with 'home' countries that generate remittance on the present scale are characterized only for first generation migrants, and become progressively weaker in subsequent generation. Further, the social implications of the positioning of remittances at the center of development strategy point further dimensions of an emerging political economy of inequality (Phillips, 2009).

Migrants put money directly into their pockets of migrants families, remittances are not panacea for development (Skeldon, 1997). The social and cultural changes affected by migration and remittances are themselves likely to affect future propensity to migrate (de Hass, 2007).

The above discussion helps to know the contribution of remittances to carry out development in migrants' origin countries. But significant positive contributions of remittances are found within household level, but not to carry out development in migrants' origin.

\section{EXPERIENCES IN THE COUNTRIES OF ORIGIN}

It is well described that international migration contributes to economic growth and poverty reduction in the migrant sending countries through labour supply, change in productivity and remittances (OECD, 2007). Latin America and Caribbean region is once again facing a crisis of development. In 2005-6, growth rates lagged behind economics in Africa, Asia and Eastern Europe. Contradiction of existing and potential development spaces for Latin America and Caribbean in the global political 
economy. It is articulated around migration-that is around the export of both skilled and unskilled labour (Philips, 2009). In the countries of origin to continue promoting labour migration in the future seem to suggest that a "culture of migration". These policies have been place for the past 30 years and other than development, remittances and the generally beneficial impacts of migration beyond the household level (Asis). More than 90 percent of labour migration recruitment in Asian countries is carried out by private recruitment agencies, which are working to develop employment opportunities in foreign countries but in many cases the nature and activities of labour recruiting agencies are found more exploitative nature rather than facilitator. In most labour sending countries policies regarding the movement of people are ad hoc in nature and related mostly to temporary international labour migration (Haque, 2002). Migrants' workers are paid much less than native workers for doing same job (Abella, Park and Bohning, 1994). Vast majority of migrants are low or semi skilled workers who are participating in migratory systems with specific characteristics: labour migration is mediated by agencies with the effect of increasing the overall cost of migration; cross border flows are of strictly temporary nature and highly regulated; migrants are subject to widespread incidences of abuse and violation of rights (ILO, 1999). 'The evidence base for the links between migration and development is still very weak' (Newland, 2007).

Migration is likely to increase as migrants' workers and their employers become dependent on each other. Migration is changing pattern and habits of consumption in receiving countries, segmenting labour market, and marginalizing certain groups especially the old and unskilled, also causing xenophobia and racism (Abellla, 1995). According to the ILO, the volume of cross border movements of workers in search for employment is likely to grow, especially in view of the fact that globalization has thus failed to generate jobs and economic opportunities where people live (ILO, 2004).

Philippine has one of the largest and longest-standing emigration programmes-yet there is little evidence that it had led to improvement in the economic and social conditions of people, nor indeed in the quality of public life. Philippines have fallen behind other countries that were economically comparable a generation ago, like Korea, Thailand and Malaysia. Deepening dependence on labor export and remittances is not a recipe for sustainable economic and social development. 'None of the Asian countries that had made the transition from country of origin to country of destination made it on the strength of deployment and /or remittances' (Asis, 2006). Mexico has had very largescale migration to USA, but this appears to have led to greater economic dependency and to economic distortions which are not conducive to economic growth (Delgado wise \& Guarnizo, 2007).

\section{MIGRATION AND DEVELOPMENT: THE 3DS, 3 R'S AND 3-D}

The GCIM (2005) has identified increasing differentials in '3Ds' as the major drivers of enhanced - Demography, Development and Democracy (Hugo, 2007). The existing 
variation in the level of '3Ds" between developing and developed regions of world the flow of international migration is found in increasing trend. Difference in '3Ds' can work as 'push' factors for origin countries and 'pull' factors for destination countries.

The 3R's summarize the impacts that migrants can have on the development of their countries of origin (Martin, 2004). Recruitment deals with persons who would have been unemployed or underemployed at home and recruitment opportunities at abroad. Remittances are the monies sent home by migrants abroad. Primarily, the volume of remittances sent by migrants' would decide the areas of investment. In most cases returning back of debt and household consumption are the main areas to be utilized of remittances. Returns refer to migrants who come back to their countries of origin. After returning back migrants their capacity with new technology enhanced or not. Their nature, age, purpose and duration of returned back and level of opportunities of learning skill at abroad plays the role to determine the impact of returned back of migrants. The 3 R's varies from persons to persons and one country to another, which make uncertain to link migration and development. In other word, if migrant is economically motivated it can set the motion in virtuous circles. In case of employed highly experienced administrator and technicians like engineer, doctor, nurses' teachers are recruited for abroad, it will creates negative impact on those fields, where they were providing services. This situation will set the motion of vicious circle, migrants neither sent remittances nor return back, if return only to rest or to enjoy retires life.

In more developed economics, certain jobs have been identified as migrants' job typically 3-D jobs (dirty, dangerous and demeaning). Most migrants are less skilled which mean their earning or remittances are also in low level than how it can foster development (Asis, 2004). The migrants' workers mostly found employed on construction and manufacturing sectors, small firms of subcontracting companies, in plantation, rice mills and fisheries. They are typically paid low salaries with little or no benefits. In the view of contemporary migration pattern being largely of short-term nature and often irregular, it is crucial to link countries of origin to countries of destination in analyzing international migration and development (Piper, 2008).

\section{CONCLUSION}

International migration is caused due to differences, mainly in the areas of 3Ds (demography, development and democracy), security and human rights between countries of origin and destinations. It has also given rise to a new socio-economic divide between households with and without access to international migration resources. Sustained inequality between international migration 'haves' and 'haves

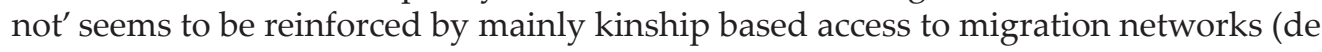
Hass, 2007). 
The role of remittances for development of origin countries depends on 3Rs (recruitment, remittances and return). Level of education and training achieved in origin and recruitment level, process, types and duration of work at destination determines migrants' earning at destination or remittances to origin. The volume of remittances determines migrants' sectors of investment from household consumption to other sectors of economy (business, land, transport, industry etc,). Saving of remittances can open the door for investment to other sectors of economy but favorable and stable social and political environment with peace and security is essential. In which purpose, how long and with what kind of skills migrants gained in destination and returned back to origin plays an important role in development origin by migrants.

The role of 3Rs is associated with 3-D jobs (dirty, dangerous and demeaning). Most of the migrants are unskilled and semiskilled therefore their main areas of work is 3-D, where the wage level is quite low and its maximum support to migrants' origin can be expected only for livelihood. Furthermore, due to the exploitative role and nature of agents/man power agencies, remittances can be only the dream of migrants and their family.

Finally, the development model of migration-remittances-development of origin countries has no sufficient ground to proof. The development level of labour exporting countries like Mexico and Philippines can be example on it. How can we say only by the flow of remittances a country can develop? Therefore, proper governmental policies and developing strong network with migrants, and bilateral relationship (short term, medium or long term) between labour sending and receiving countries remittances can help for development. The proper environment of political and economic motivation for development in origin; migrants' opportunities of gaining financial and human capital at destination; migrants own preferences of investment and migrants attitudes towards home countries are too important. It may not be practical to globalize international migration-remittances-development in migrants' country of origin.

\section{References}

Abella, M. (1995). The international movement of labour in Asia. Geneva: ILO

Abella, M.I. \& Park, Y.B.(1994). Adjustments to labour shortages and foreign workers in the republic of Korea. Geneva: ILO International Migration Papers.

Asis, M. (2004). Safety net for all time. Philippines 2015 Glimpses of the Future.

Asis, M. (2005). Recent trends in international migration in Asia and the Pacific. AsiaPacific Population Journal, 20, 15-38.

Asis, M. (2006). The Philippines' culture of migration, migration information source. Washington, DC: Migration Policy Institute. 
Black, R., Natali, C. \& Skinner, J. (2005). 'Migration and inequality', equity \& development, world development report 2006, Background Papers, Development Research Centre on Migration, University of Sussex.

Bohning, W.R. (1994). Undesired jobs and what one can do to fill them: The case of the republic of Korea.

Carney De. (1998). Sustainable rural livelihoods. What contribution can we make? London: DFID

Casteles, S. (2008). Development and migration-migration and development: What comes first? (A paper presented to Social Science Research Council Conference, 28 February- 1 March), New York. www.essays.ssrc.org/developmentpapers/ wp-content/uploads/2cCastels.pdf, accessed on January 10, 2011.

CDR (2002). The migration-development nexus. Copenhagen: Centre for Development Research.

CEC (2005). Policy plan on legal migration. Brussels: Commission of the European Communities, December 21, 2005.

Coudenhove-Kalergi, R. N. (1929). 'Africa', Paneuropa 5(2).

DANG, A. (2005). Enhancing the development impact of migrant remittances and diaspora: the case of Vietnam. Asia-Pacific Population Journal.

De Haas H. (2008). Irregular migration from West Africa to the Maghreb and the European Union: An overview of recent trends. Geneva: International Organization for Migration.

De Haas, H. (2007). Remittances, migration and social development: A conceptual review of literature, social policy and development program paper no. 34 .New York: UN Research Institute for Social Development.

Delgado Wise, R. \& Guarnizo, L. E. (2007). Migration and development: Lessons from the Mexican experience. Accessed 6 February 2007, Washington DC: Migration Information Source, http://www.migrationinforamtion.org.

Esmeralda Rodriguez-Scott (2002). Patterns of Mexican migration to the United States. Paper prepared for delivery at 82nd annual meeting of the southwestern Social Science Association, March 27- 30, 2002. University of St. Thomas: Center for International studies, available at www/appstate.edu/stefanov/proceedings/ rodrignez.htm

Global Commission on International Migration, GCIM (2005). Migration in an interconnected world: New directions for action. Report of the global commission on international migration. Geneva: GCIM

Haque, Md. S. (2002). Dynamics of Labour Migration Process in Bangladesh. WARBE Newsletter Vol. 2, Dec. 
Harris, J. R., \& Todaro, M. (1970). Migration, unemployment and development: A twosector analysis. American Economic Review, 60, 126-142.

Hugo, G.(2007). International migration and development in Asia, Presentation to 8th International Conference of the Asia Pacific Migration Research Network on the theme of 'Migration, Development and Poverty Reduction, Fuzhou, China, 25-29 May 2007, available at: http://apmrn.usp.ac.fj/conferences/8thAPMRNco nference/1.Hugo.pdf, accessed January 18, 2010.

International Labour Organization (1999). Conclusions and recommendations., AsiaPacific Regional Symposium for Trade Union Organizations on Migrant Workers, 6-8 December 1999, Petaling Jaya, Malaysia. http://www.ilo.org/public/english/ dialogue/actrav/genact/socprot/migrant/ migrant1.htm; (downloaded June, 2005)

International Labour Organization, ILO, (2004). Towards a far deal for migrant workers in the global economy, ILO Report Prepared for ILO Conference 92nd Session. Geneva: ILO

International Organization for Migration, IOM, (2008). Migration and development: Achieving policy coherence No (34). Geneva: IOM Migration Research Series.

Kapur, D. (2003). Remittances: The new development mantra. Paper prepared for the Group of twenty-four technical group meeting, August, 2003.

Kapur, D. \& McHale, J. (2005). Give us your best and brightest: a global hunt for talent and its impact on the developing world, Center for Global Development, Washington, D.C.

Kapur, D. (2004). Remittances: The new development mantra? Palais des Nations, Geneva.

Katseli LT, Lucas REB, \& Xenogiani, T. (2006). Effects of migration on sending countries: What do we know? Working Paper No. 250, OECD, Paris

Mabogunje, A.L. (1970). Systems approach to a theory of rural urban migration. Geographical Analysis, 2(1), 118.

Massey, D.S., Arango, J, Hugo, G, Kouaouc, A., Pellegrino A., \& Taylor, J.E. (1998). Worlds in motion: Understanding international migration at the end of the millennium. Oxford: Clarendon Press

Martin, P. (2004). Migration and development: toward sustainable solutions. Decent work research programme. Geneva: International Organization for Migration.

Newland, K. (2007). New surge of interest in migration and development. Accessed 6 February 2007, Washington DC: Migration Information Source, www. migrationinformation.org. 
Organization for Economic Cooperation and Development (OECD) (2007). Promoting pro-poor growth: Key policy messages. Paris: OECD

Phillips, N. (2009).Migration as development strategy? The new political economy of dispossession and inequality in Americas. Review of International Political Economy, 16(2), 231-259.

Piper, N. (2008). Feminisation of migration and the social dimensions of development: The Asian case. Third World Quarterly, 29(7), 1287-1303.

Ratha D. (2003). Workers' remittances: An important and stable source of external development finance. Global Development Finance. Washington D.C.: World Bank.

Stark, O. (1978). Economic-demographic interactions in agricultural development: the case of rural-to-urban migration. Rome: FAO.

Stark, O. (1991). The migration of labor. Cambridge and Oxford: Blackwell.

Skeldon, R. (1997). Migration and development: A global perspective. Harlow: Longman.

Todaro, M.P. (1969). A model of labor migration and urban unemployment in lessdeveloped countries. American Economic Review, 59,138-48.

United Nations (2006). International Migration and Development (United Nations: General assembly Agenda item 54 (c) Globalization and interdependence: international migration and development). United Nations

Wallerstein, I. (1974). The modern world system I, capitalist agriculture and the origins of the European world economy in the sixteenth century. New York: Academic Press

Wallerstein, I. (1980). The modern world system II, mercantilism and the consolidation of the European world-economy, 1600-1750. New York: Academic Press

Zelinsky, Z. (1971). The hypothesis of the mobility transition. Geographical Review $61,219-49$ 